\title{
The role of PPARY in carbon nanotube-elicited granulomatous lung inflammation
}

\author{
Isham Huizar', Anagha Malur', Janki Patel', Matthew McPeek', Larry Dobbs², Christopher Wingard³, \\ Barbara P Barna ${ }^{1}$ and Mary Jane Thomassen ${ }^{1,4^{*}}$
}

\begin{abstract}
Background: Although granulomatous inflammation is a central feature of many disease processes, cellular mechanisms of granuloma formation and persistence are poorly understood. Carbon nanoparticles, which can be products of manufacture or the environment, have been associated with granulomatous disease. This paper utilizes a previously described carbon nanoparticle granuloma model to address the issue of whether peroxisome proliferator-activated receptor gamma (PPARY), a nuclear transcription factor and negative regulator of inflammatory cytokines might play a role in granulomatous lung disease. PPARy is constitutively expressed in alveolar macrophages from healthy individuals but is depressed in alveolar macrophages of patients with sarcoidosis, a prototypical granulomatous disease. Our previous study of macrophage-specific PPARY KO mice had revealed an intrinsically inflammatory pulmonary environment with an elevated pro-inflammatory cytokines profile as compared to wild-type mice. Based on such observations we hypothesized that PPARY expression would be repressed in alveolar macrophages from animals bearing granulomas induced by MWCNT instillation.
\end{abstract}

Methods: Wild-type C57BI/6 and macrophage-specific PPARY KO mice received oropharyngeal instillations of multiwall carbon nanotubes (MWCNT) $(100 \mu \mathrm{g}$ ). Bronchoalveolar lavage (BAL) cells, BAL fluids, and lung tissues were obtained 60 days post-instillation for analysis of granuloma histology and pro-inflammatory cytokines (osteopontin, $\mathrm{CCL} 2$, and interferon gamma [IFN- $\gamma]$ mRNA and protein expression.

Results: In wild-type mice, alveolar macrophage PPARY expression and activity were significantly reduced in granuloma-bearing animals 60 days after MWCNT instillation. In macrophage-specific PPARY KO mice, granuloma formation was more extensive than in wild-type at 60 days after MWCNT instillation. PPARY KO mice also demonstrated elevated pro-inflammatory cytokine expression in lung tissue, laser-microdissected lung granulomas, and BAL cells/fluids, at 60 days post MWCNT exposure.

Conclusions: Overall, data indicate that PPARY deficiency promotes inflammation and granuloma formation, suggesting that PPARy functions as a negative regulator of chronic granulomatous inflammation.

\section{Background}

Investment in nanotechnology is currently estimated to constitute approximately 18 billion dollars nationally, with commercial products ranging from sunscreens to bicycle frames [1]. While the environmental and occupational health impacts of nanotechnology remain to be established, evidence of toxicity has emerged from some

\footnotetext{
* Correspondence: thomassenm@ecu.edu

${ }^{1}$ Department of Internal Medicine, Division of Pulmonary and Critical Care Medicine, The Brody School of Medicine, East Carolina University, 3E-149 Brody Medical Sciences Building, Greenville, NC 27834, USA

${ }^{4}$ Department of Microbiology and Immunology, East Carolina University, Greenville, USA

Full list of author information is available at the end of the article
}

experimental models where carbon-based nanomaterials persist for long periods in lung tissue and induce granulomatous changes (reviewed in [2,3]. Granulomatous disease may occur in human lung in response to a wide spectrum of environmental stimuli including intracellular pathogens, inert materials, and organic antigens. In sarcoidosis, a prototypical granulomatous disease, the etiology remains obscure [4]. Multiple occupational and environmental risk factors have been linked to sarcoidosis, including exposure to particulates from wood-burning stoves, fireplaces, firefighting, and the World Trade Center disaster - conditions that favor carbon nanotube formation in ambient air [5-8].

\section{Biomed Central}


Granulomatous changes have been reported in association with instillation of single wall carbon nanotubes [9-11]. We recently reported a novel murine model of chronic granulomatous inflammation elicited by exposure to multiwall carbon nanotubes (MWCNT) [12]. This model demonstrated several key similarities with granulomas encountered in human sarcoidosis: (a) chronicity with persistence up to 90 days; (b) macrophage and T cell recruitment; and (c) marked elevation of inflammatory cytokines [12]. Previously published murine granuloma models utilized sepharose beads to elicit acute granulomas that formed and resolved within three weeks [13].

The transcription factor, PPAR $\gamma$, is a critical regulator of lipid and glucose metabolism but also recognized as a negative regulator of genes linked to inflammatory events [14]. Alveolar macrophages of healthy individuals constitutively express PPAR $\gamma$ but PPAR $\gamma$ is deficient in alveolar macrophages from patients with severe sarcoidosis, suggesting that this factor represents an important regulator of inflammation [15]. Based on these observations we hypothesized that PPAR $\gamma$ might play a role in the formation of MWCNT granulomas. To address this hypothesis we first examined the effects of MWCNT instillation on PPAR $\gamma$ expression and activity in wild-type mice. Secondly, we investigated the effect of pre-existing PPAR $\gamma$ deficiency on MWCNT-elicited granulomas by utilizing macrophage-specific PPAR $\gamma$ KO mice. Results suggested that PPAR $\gamma$ functions as a negative regulator of granuloma formation in response to MWCNT instillation.

\section{Methods}

All studies were conducted in conformity with Public Health Service (PHS) Policy on humane care and use of laboratory animals and were approved by the institutional animal care committee.

\section{Mice}

C57BL/6J wild-type mice from Jackson Laboratories and macrophage-specific PPAR $\gamma \mathrm{KO}$ conditional mice as previously described [16] were utilized in experiments as indicated.

\section{Characterization of carbon nanotubes}

MWCNTs (catalogue number 900-1501, lot GS1801), grown via chemical vapor deposition, were obtained from SES Research (Houston, TX). We determined the structure of MWCNTs by scanning electron microscopy. Nitrogen adsorption studies were performed using a physisorption analyzer (ASAP 2010; Micromeritics, Norcross, GA). The details of the MWCNT characterization were previously described by Huizar et al. [12].

\section{Instillation of carbon nanotubes}

Procedures were performed according to the East Carolina University Office of Environmental Health and Safety. An oropharyngeal instillation was performed after sedation with isofluorane. Sixty days after sham treatment (PBS/35\% surfactant) or exposure to $100 \mathrm{ug}$ MWCNT, the mice were sacrificed, and bronchoalveolar lavage (BAL) or lungs were harvested for further analysis as previously described [12].

\section{Histological analysis}

Lungs were dissected and fixed in PBS-buffered $4 \%$ formaldehyde. A semiquantitative scoring system was devised to allow for a relative comparison of the numbers and quality of the granulomas formed in the C57 and PPAR $\gamma$ mice strains. The glass slides with the Hematoxylin and Eosin stained sections of lung from each of the experimental mice was assigned a score of between 0 and 5 by two independent investigators using the following scoring system: (score 0) - no granulomas or aggregates of macrophages seen; (score 1) - few small groups of macrophages but no well-formed granulomas; (score 2) - scattered small granulomas not easily seen on scanning power (20X); (score 3) - scattered small granulomas easily seen on scanning power (20X); (score 4) - scattered small granulomas with occasional larger granulomas seen on scanning power (20X); (score 5) - numerous large granulomas easily seen on scanning power. The scores obtained by the two investigators were averaged for the final analysis.

\section{Bronchoalveolar Lavage (BAL)}

BAL cells were obtained as previously described [16]. Differential cell counts were determined from cytospins stained with a modified Wright's stain. Mean viability of lavage cells was greater than $95 \%$ as determined by trypan blue dye exclusion.

\section{RNA purification and analysis}

Total RNA was extracted from total BAL cells by RNeasy protocol (Qiagen, Valencia, CA). Expression of mRNA was determined by real time qPCR using the ABI Prism 7300 Detection System (TaqMan; Applied Biosystems, Foster City, CA) according to the manufacturer's instructions. RNA specimens were analyzed in duplicate using primer sets for IFN- $\gamma$, osteopontin, and CCL2 (MCP-1). Threshold cycle (CT) values for genes of interest were normalized to a housekeeping gene glyceraldehyde 3 phosphate dehydrogenase, (GAPDH) as previously described [16]. Data were expressed as a fold change in mRNA expression of MWCNT-bearing mice relative to sham control values.

\section{Immunocytochemistry}

Immunocytochemistry was performed on cytospin preparations from freshly isolated $\mathrm{C} 57 \mathrm{Bl} / 6$ alveolar macrophages for basal expression levels of PPARy (Santa Cruz 
Biotech, Santa Cruz, CA). Slides were fixed with $4 \%$ paraformaldehyde-PBS, then permeabilized with Triton X-100 and stained with anti-PPAR $\gamma$ antibody at 1:500 dilution, followed by Alexa conjugated goat anti rabbit IgG (Invitrogen). Staining of lung tissues with antibody to IFN- $\gamma, \mathrm{CD} 3$ and MOMA2 (anti-monocyte and macrophage) was carried out as described previously [16]. Slides were counter stained with Propidium Iodide (PI) [Vector Laboratories] or DAPI (Invitrogen) to facilitate nuclear localization.

\section{Laser-capture microdissection}

Lung tissues from sham-treated mice (controls) and both granulomatous, and non-granulomatous lung tissues from MWCNT-instilled mice were dissected using a Zeiss PALM IV LCM (Carl Zeiss MicroImaging LLC, Thornwood, New York) system. Frozen sections of the lung were processed as previously described [12]. RNA was extracted from tissue sections, converted into cDNA or preamplified, as described previously [12].

\section{Quantitation of cytokine proteins}

Murine osteopontin was quantified in BAL fluids using an ELISA assay (R\&D stystems, Minneapolis, MN), as previously described [12]. Murine IFN- $\gamma$ and CCL2 (MCP-1) were quantified by electrochemiluminescence detection (Meso Scale Diagnostics, Gaithersburg, MD).

A

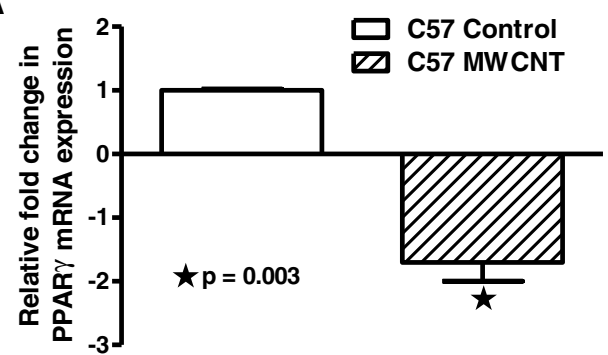

B

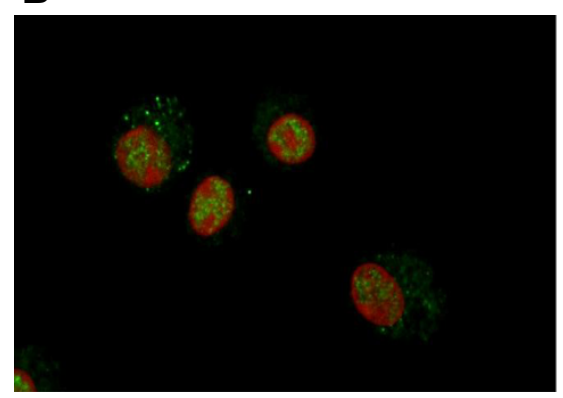

C57 Control

D

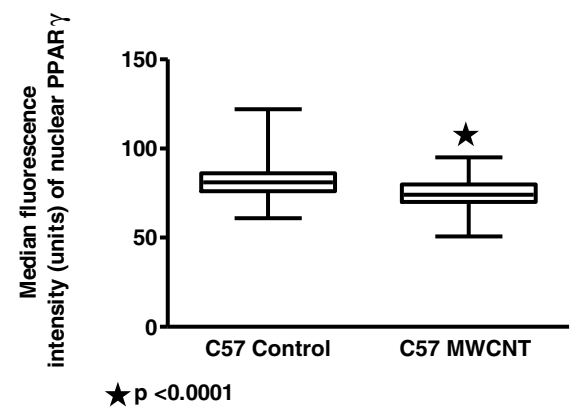

C

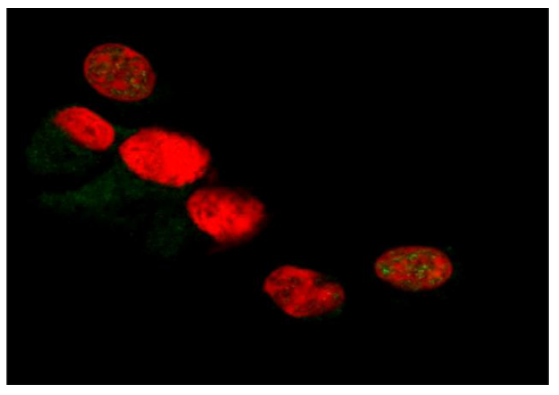

C57 MWCNT 60 Day

E

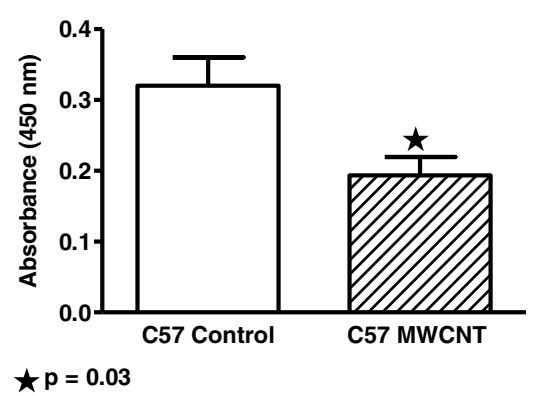

Figure 1 PPARy expression and activity are decreased in BAL from MWCNT-instilled wild-type C57BI/6 mice. (A) BAL cell mRNA samples from MWCNT or sham-treated mice ( $n=4 /$ group) were analyzed by quantitative PCR. PPARY mRNA was significantly decreased $(p=0.003) 60$ days post MWCNT instillation. Immunocytochemistry of alveolar macrophages collected by cytospins demonstrated decreased nuclear staining for PPARY protein at 60 days after MWCNT instillation (C) compared to sham controls (B). (Nuclei were counterstained with propidium iodide). (D) Quantification of PPARy fluorescence intensity of alveolar macrophages in immunostained cytospins ( $\mathrm{n}=99$ cells/slide) indicated MWCNT exposure significantly reduced PPARy expression ( $n=5 /$ group). (E) PPARy binding activity was reduced in alveolar macrophages of MWCNT-treated mice ( $n=3 /$ group) as measured by ELISA. 


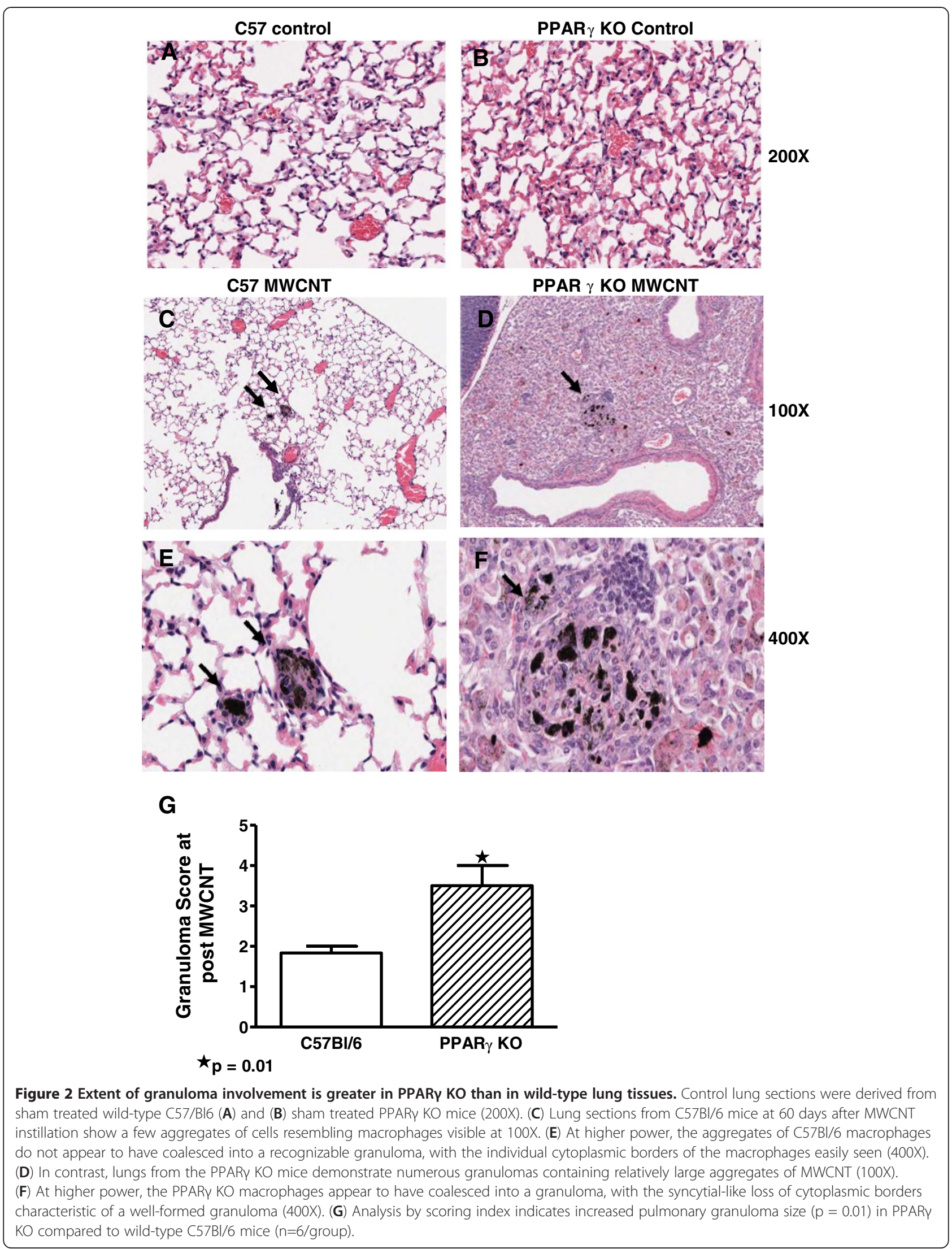




\section{Statistical analyses}

Data were analyzed by student's t-test or Mann-Whitney using Prism software (GraphPad, Inc., San Diego, CA.). Values from treated were compared to sham treated animals. Data are expressed as mean \pm SEM. Significance was defined as $\mathrm{p} \leq 0.05$.

\section{Results}

PPAR $y$ expression and activity are decreased in alveolar macrophages from MWCNT-instilled wild-type C57BI/6 mice Analysis of mRNA derived from BAL cells revealed significant reduction of PPAR $\gamma$ mRNA expression in wild-type mice at 60 days after MWCNT (100 ug) instillation as compared to sham controls (Figure 1A). Direct examination of alveolar macrophage PPAR $\gamma$ expression by immunocytochemistry confirmed reduction of PPAR $\gamma$ protein at 60 days of MWCNT exposure (Figures 1B-D). Similarly, PPAR $\gamma$ DNA-binding activity also decreased (Figure 1E). Thus all parameters indicated that MWCNT instillation into the lung induced severe and significant repression of alveolar macrophage PPAR $\gamma$ expression and functional activity at 60 days of exposure.

\section{Granuloma formation in macrophage-specific PPARY KO} mice exceeds that of wild-type animals

To examine the effects of pre-existing PPAR $\gamma$ deficiency on MWCNT granuloma formation, MWCNT (100 $\mu \mathrm{g})$ were instilled into lungs of macrophage-specific PPAR $\gamma$ $\mathrm{KO}$ and into wild-type mice. For reference, histologic sections from untreated $\mathrm{C} 57 / \mathrm{Bl} / 6$ (Figure 2A) and PPAR $\gamma \mathrm{KO}$ (Figure 2B) are provided. Granuloma formation was evaluated at 60 days of MWCNT exposure. Histologic comparison of wild-type $\mathrm{C} 57 \mathrm{Bl} / 6$ (Figure $2 \mathrm{C}$ and E) and PPARy KO (Figure 2D and F) lung tissues was carried out using a simplified scoring system taking into account size and frequency of granulomas. Results indicated that the extent of granuloma formation in PPAR $\gamma$ KO mice was significantly $(\mathrm{p}=0.01)$ greater than in wild-type mice (Figure 2E).

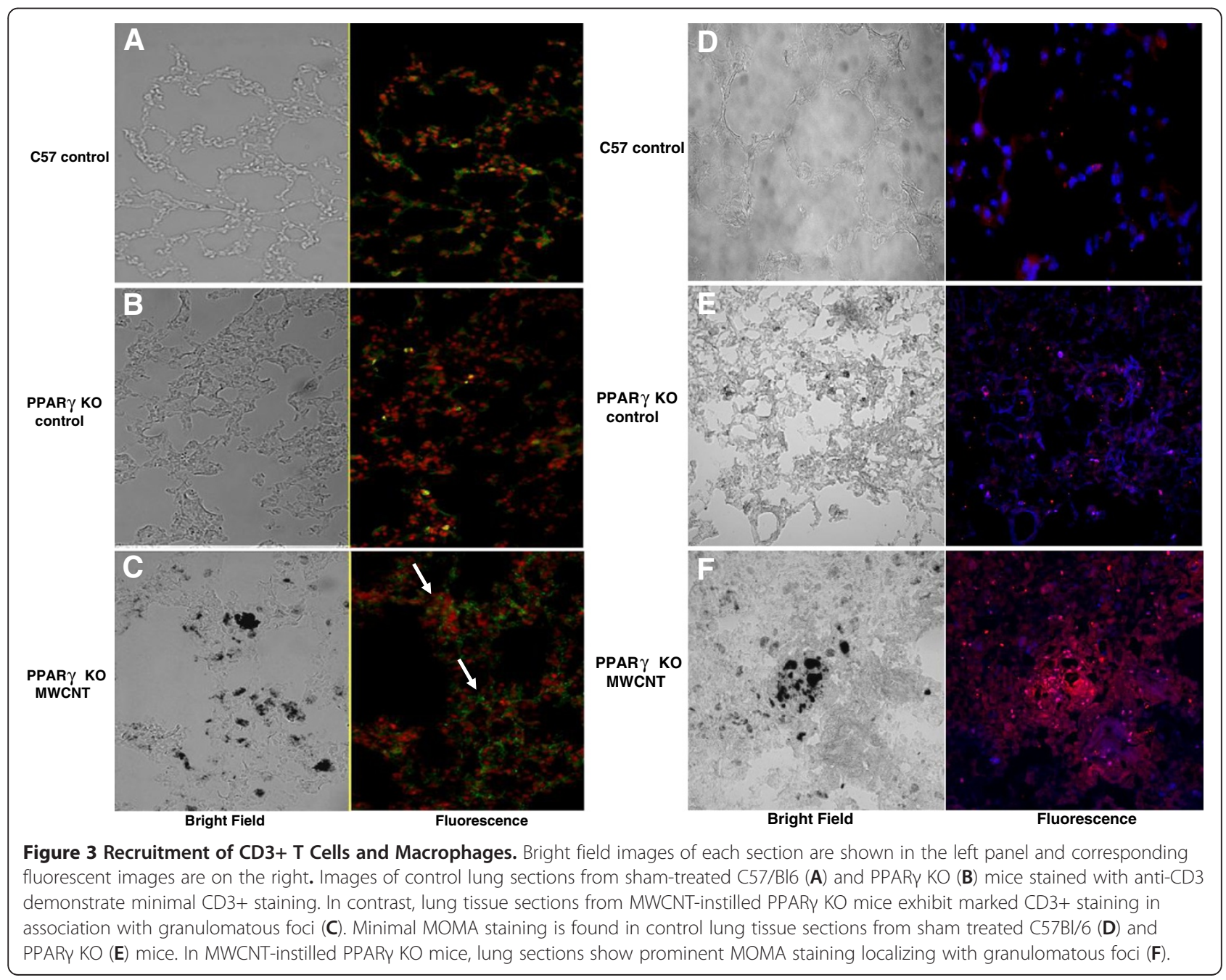




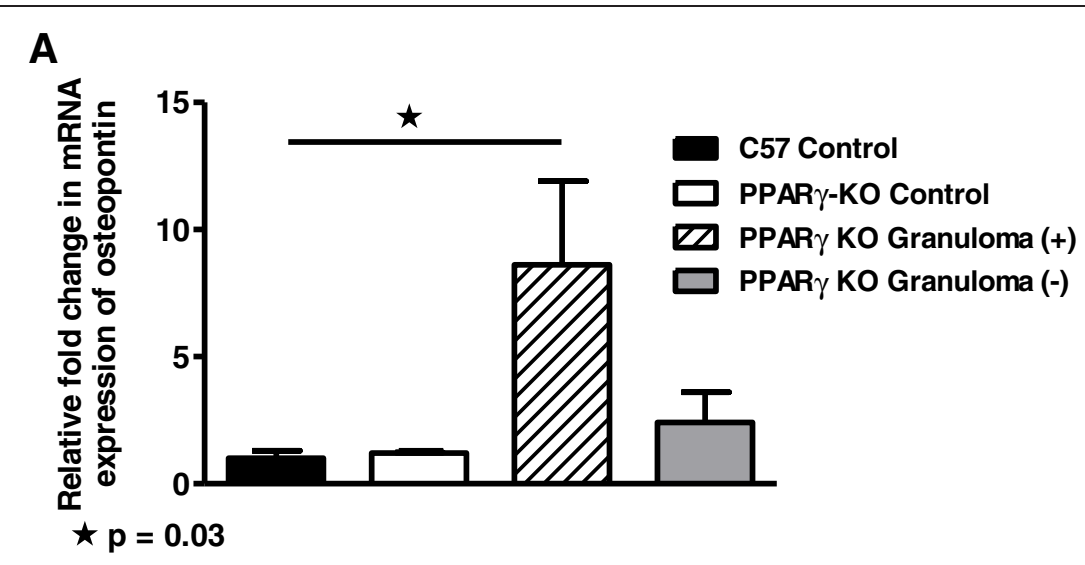

B
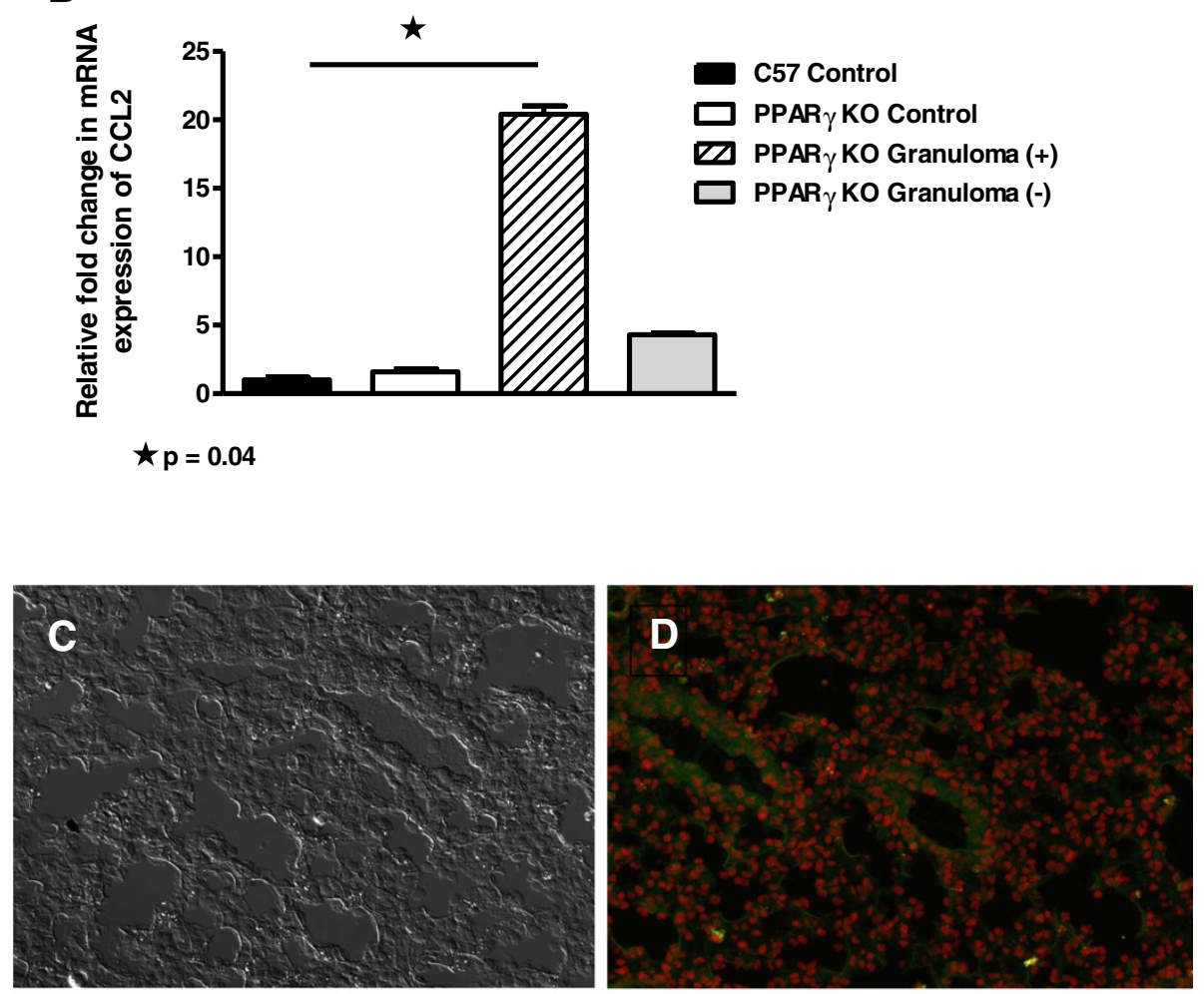

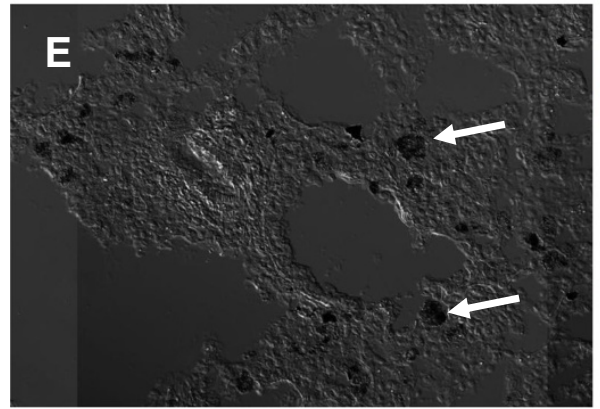

Bright Field

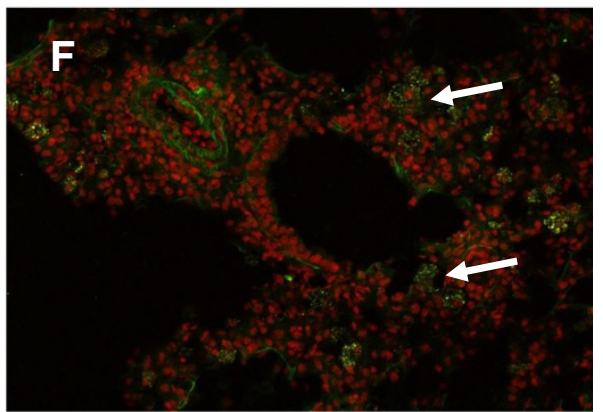

Fluorescence 
(See figure on previous page.)

Figure 4 Granulomatous tissues contain elevated pro-inflammatory cytokine expression in macrophage-specific PPAR $\mathrm{KO}$ mice. QPCR of PPARY KO lung tissues obtained by laser capture microdissection reveal elevated mRNA expression of osteopontin $(\mathbf{A})(p=0.03)$ and CCL2 (B) $(p=0.04)$ in granulomatous foci (MWCNT) compared to control wild type lung tissues ( $n=2 /$ group). Unstained PPARY KO lung tissue sections (200x) were obtained from control lung (C) or MWCNT-instilled lung (E). Arrows point to MWCNT within granulomas (E). Additional lung tissue sections were stained with antibody to IFN- $\gamma$ and counterstained with propidium iodide to localize nuclei: (D) Sham control lung; (F) MWCNTinstilled lung. Arrows point to IFN- $\gamma$-positive cells within granulomatous foci (F).

\section{Recruitment of CD3+ T cells and macrophages}

In order to identify cell types associated with granulomatous tissue, lung sections from nanotube-instilled mice were stained with anti-CD3 ( $\mathrm{T}$ cells) and anti-MOMA (monocytes and macrophages). Figures $3 \mathrm{~A}$ and $\mathrm{B}$ show minimal $\mathrm{CD} 3+$ staining in tissue sections from sham treated $\mathrm{C} 57 / \mathrm{Bl6}$ or PPAR $\gamma \mathrm{KO}$ control mice. In contrast, marked $\mathrm{CD} 3+$ staining is apparent in association with granulomas in nanotube-instilled mice (Figure 3C). Similarly, Figures $3 \mathrm{D}$ and $\mathrm{E}$ demonstrate minimal MOMA staining in lung tissues from sham treated mice but prominent MOMA staining localizing with granulomatous foci in nanotube-instilled mice (Figure 3F).

\section{Pro-inflammatory cytokines are elevated in granulomatous tissue}

BAL cell counts were not affected by MWCNT exposure (data not shown), however, as we noted previously, lymphocyte counts from untreated PPARY KO mice (7.6 $\pm 1.4 \%)$ were significantly $(\mathrm{p}=0.005)$ higher than those of wild-type (3.2 $\pm 0.6 \%)$ [16]. Examination of lung tissues by laser microdissection and $\mathrm{qPCR}$ revealed that mRNA expression of osteopontin, a granuloma-promoting chemokine [17], was elevated in granulomatous foci compared to wild type sham control lung tissues (Figure 4A). Previously in wild-type mice we found that osteopontin was elevated 20 -fold in granulomatous foci at 60 days whereas nongranulomatous tissue did not differ from untreated lung tissue [12]. Elevated expression of the monocyte chemokine, CCL2 [18] was also prominent in granuloma foci compared to control wild type tissue (Figure 4B). CCL2 expression in granulomas was also investigated previously in wild-type mice and found to be elevated 6-fold compared with lung tissue from controls [12]. Although elevation of mRNA from the prototypical inflammatory cytokine, interferon gamma (IFN- $\gamma$ ), was below detectable limits in LCM samples of granulomatous foci, immunostaining confirmed the presence of numerous IFN- $\gamma$-expressing cells within 60-day MWCNT-induced granulomas (Figures 4E and F). In contrast, sham control lung tissue contained few such cells (Figures 4C and D).

\section{Pro-inflammatory Cytokines are elevated in BAL cells and fluids from MWCNT-instilled PPARY KO mice}

Because previous findings in BAL cells from wild-type mice indicated elevation of pro-inflammatory cytokines at
60 days after MWCNT instillation [12], we investigated BAL cells in macrophage-specific PPAR $\mathrm{KO}$ mice. Sixty days after MWCNT instillation, PPAR $\mathrm{KO}$ BAL cells contained elevated mRNA expression levels of osteopontin (Figure 5A) and CCL2 (Figure 5B) compared to sham $\mathrm{C} 57 / \mathrm{Bl} 6$ or PPAR $\gamma \mathrm{KO}$ controls. IFN- $\gamma$ mRNA was also elevated in nanotube-instilled PPAR $\gamma$ KO compared to sham control PPARY KO (Figure 5C). Previously, we had reported that IFN- $\gamma$ mRNA was elevated in untreated PPAR $\gamma \mathrm{KO}$ mice compared to untreated wild-type C57Bl/6 [13]. Analysis of BAL fluids also demonstrated elevated osteopontin (Figure 5D) and CCL2 (Figure 5E) proteins at 60 days post-MWCNT instillation. Although IFN- $\gamma$ protein was apparent within granulomas (Figure 4F), IFN- $\gamma$ was below detectable limits in BAL fluids.

\section{Discussion}

Data from the present study indicate that both expression and activity of PPAR $\gamma$ in alveolar macrophages from wildtype mice were significantly diminished at 60 days after pulmonary instillation of nanotubes. These data supported previous findings of reduced PPAR $\gamma$ in alveolar macrophages from patients with the human chronic granulomatous disease, sarcoidosis [15]. Investigation of the effects of pre-existing PPAR $\gamma$ deficiency was achieved by utilizing a conditional mouse model in which PPAR $\gamma$ was specifically disrupted in macrophages and neutrophils [16]. Results from this model revealed elevated pro-inflammatory cytokines in granulomatous tissue, BAL cells, and BAL fluids 60 days post-instillation of MWCNT. Histological examination of lung tissues from MWCNT-exposed animals also indicated a greater extent of granuloma formation in PPARY KO mice than in MWCNT-exposed wild-type animals.

The stimulatory effects of MWCNT instillation on cytokine production were noted previously in wild-type C57Bl/ 6 mice [12]. The current report also indicates that MWCNTs repress PPARY expression in wild-type mice, raising the question of whether PPAR $\gamma$ deficiency augments pro-inflammatory cytokine expression. Previously, we reported that IFN- $\gamma$ and other Th1-type pro-inflammatory cytokines/chemokines were intrinsically elevated in untreated PPAR $\gamma$ KO mice compared to wild-type mice [16]. This increased cytokine expression was reduced by in vivo administration of a PPAR $\gamma$ lentivirus construct [16]. Additionally, application of a PPAR $\gamma$ antagonist to 


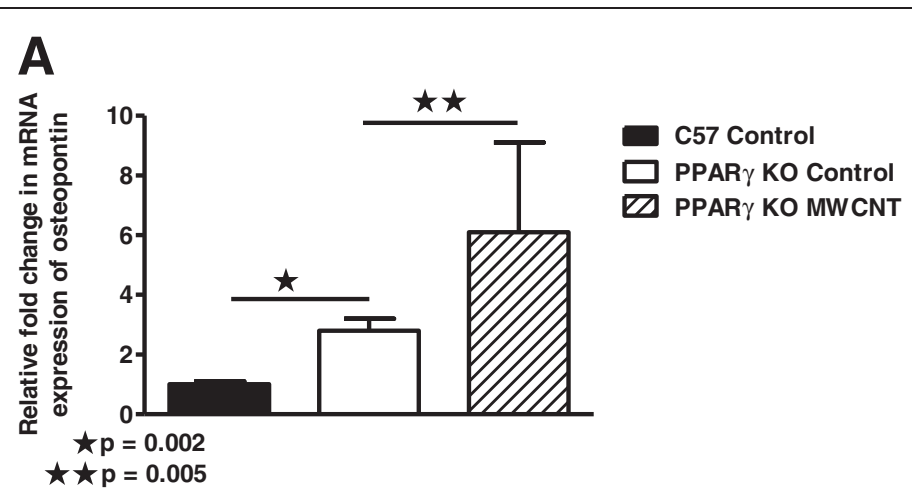

B

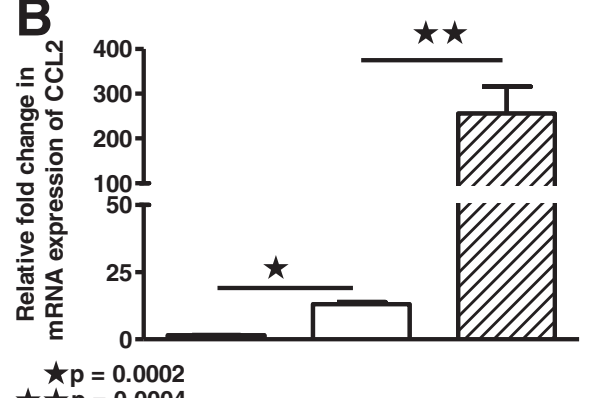

C57 Control

$\square$ PPAR $\gamma$ KO Control ZD PPAR $\gamma$ KO MWCNT

$\star \star \mathrm{p}=0.0004$

C

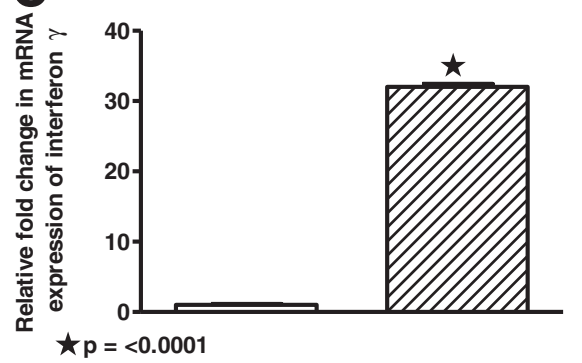

$\square$ PPAR $\gamma$ KO Control

D PPAR $\gamma$ KO MWCNT

D

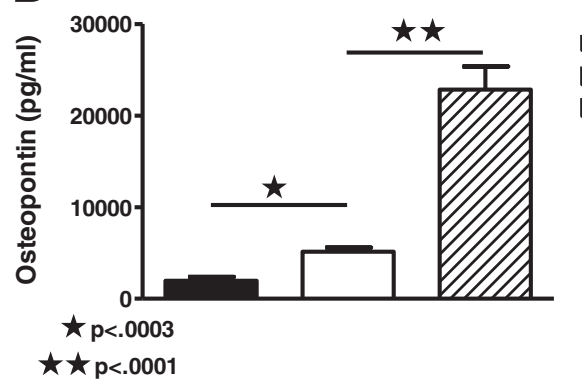

C57 Control
PPAR $\gamma$ KO Control $\square$ PPAR $\gamma$ KO MWCNT

E

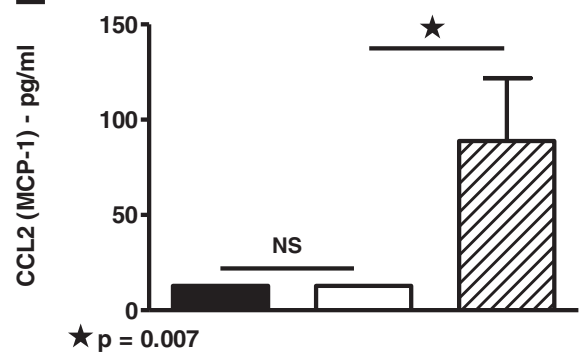

C57 Control

$\square$ PPAR $\gamma$ KO Control एDPAR $\gamma$ KO MWCNT

Figure 5 (See legend on next page.) 
(See figure on previous page.)

Figure 5 Pro-inflammatory cytokines are elevated in BAL cells and fluids from macrophage-specific PPAR $\boldsymbol{K}$ KO mice 60 days postinstillation of MWCNT. (A) MWCNT instillation of PPARY KO mice $(n=8)$ significantly increases BAL cell osteopontin mRNA expression compared to sham C57/BI6 ( $n=7)$ or PPARy KO $(n=6)$ controls. (B). CCL2 mRNA expression is increased in MWCNT-instilled PPARy KO mice ( $n=11)$ compared to sham C57/BI6 ( $n=9)$ or PPARY KO $(n=8)$ controls. (C) IFNy mRNA expression is increased in MWCNT-instilled PPARY KO ( $n=11)$ compared to PPARY KO controls ( $n=8)$. BAL fluids from MWCNT-exposed PPARY KO mice contain elevated: (D) osteopontin compared to sham C57BI/6 or

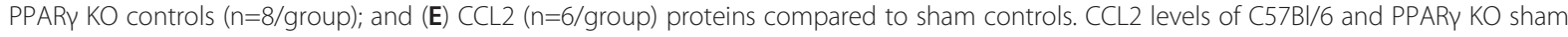
control groups were below detectable limits of the assay $(12.8 \mathrm{pg} / \mathrm{ml})$.

healthy wild-type alveolar macrophages in vitro resulted in an elevated cytokine profile resembling the PPAR $\gamma \mathrm{KO}$ phenotype [16]. When taken together, current and previous data allows us to hypothesize that healthy alveolar macrophage PPAR $\gamma$ expression is necessary to restrain pro-inflammatory cytokine expression and maintain pulmonary integrity.

Despite the presence of elevated intrinsic cytokines in PPARY KO mice compared to wild-type controls, MWCNT instillation further elevated cytokine expression when compared to sham PPAR $\gamma \mathrm{KO}$ controls. Cytokines elevated by MWCNT exposure in PPAR $\gamma \mathrm{KO}$ mice included osteopontin, which was found in granuloma tissue, BAL cells and fluids. Osteopontin is a noncollagenous matrix protein with cytokine properties that include cellular activation, migration and cell-matrix interaction in $\mathrm{T}$ lymphocytes, macrophages, and fibroblasts $[17,19]$. Osteopontin is abundant in granulomas of varying etiology [20] and deficiency of this molecule in null mice impairs granuloma formation [17]. Gene expression of osteopontin is antagonized by PPARY ligands, thus suggesting a direct avenue by which PPAR $\gamma$ may attenuate granuloma formation [21].

Interestingly, osteopontin is reported to increase $\mathrm{T}$ cell expression of IFN- $\gamma$ [22] and IFN- $\gamma$ has been shown to induce osteopontin in monocyte-derived macrophages [23]. Thus it is possible that IFN- $\gamma$ and osteopontin may interact in a positive feedback loop to maintain high levels in untreated PPAR $\gamma \mathrm{KO}$ mice. In human sarcoidosis, both osteopontin and IFN- $\gamma$ are prominent in granulomas $[24,25]$ and IFN $-\gamma$ is persistently elevated in sarcoidosis BAL cells [26-28].

BAL cells from untreated PPAR $\gamma \mathrm{KO}$ mice also exhibited higher intrinsic mRNA levels of CCL2 (MCP-1), a potent monocyte chemokine [18] than did BAL cells from wild-type mice. Previously we noted that CCL2 expression in wild-type $\mathrm{C} 57 \mathrm{Bl} / 6$ mice became elevated at sixty days post-instillation of MWCNT [12]. CCL2 was also further elevated in PPARY KO BAL cells at 60 days post MWCNT instillation. Interestingly, elevated CCL2 is also present in sarcoidosis BAL cells and fluids [29] as well as serum [30]. Overall, the evidence for elevated CCL2 in human sarcoidosis and in MWCNT-instilled wild-type and PPAR $\gamma \mathrm{KO}$ mice suggests that this chemokine is an important element of inflammatory pulmonary granuloma formation.
PPAR $\gamma$ plays an important role in the negative regulation of inflammation by inhibiting the gene expression of numerous cytokines including osteopontin and CCL2. Reported mechanisms of PPAR $\gamma$-mediated transrepression include: (a) binding of NF-kB, (b) induction of $\mathrm{I} \kappa \mathrm{B} \alpha$ expression (c) inhibition of MAPK activity, (d) competition for coactivators (e.g. CREB-binding proteins), and (e) blocking clearance of NCoR corepressor complexes [31]. Thus in the current study, we hypothesize that a lack of PPAR $\gamma$-mediated transrepression may be responsible for augmenting granulomatous reactions in macrophagespecific PPAR $\gamma$ KO mice via concurrent upregulation of cytokines (osteopontin and CCL2) involved in granuloma formation.

\section{Conclusion}

Chronic granulomatous inflammation in response to chemical or biological insult has proven to be a difficult disease to control, despite years of research. Nanoparticles have only recently been implicated as potential causes of granuloma formation that may relate to either occupational or environmental exposures [32]. The persistent nature of the MWCNT granuloma model parallels that of human granulomatous disorders and emphasizes the applicability of this model to studies of human granuloma pathophysiology. The current findings provide a new perspective on the critical role of alveolar macrophage PPAR $\gamma$ in lung homeostasis by demonstrating negative effects on granuloma formation.

\section{Competing interests}

The authors have no financial competing interest.

\section{Authors' contribution}

$\mathrm{IH}$ contributed to acquisition of the data, analysis and interpretation of data, drafting of the manuscript and final approval of the version to be published. AM contributed to acquisition of the data, analysis and interpretation of data, drafting of the manuscript and final approval of the version to be published. JP contributed to the acquisition of data and final approval of the version to be published. MM contributed to the acquisition of data and final approval of the version to be published. LD contributed to the acquisition of data and final approval of the version to be published. CW contributed to the conception and characterization/preparation of nanotubes. BPB contributed to the design, analysis and interpretation of data, drafting of the manuscript and final approval of the version to be published. MJT contributed to the design, analysis and interpretation of data, drafting of the manuscript and final approval of the version to be published. All authors read and approved the final manuscript. 


\section{Acknowledgments}

We thank MeShall Hills for her superb technical expertise. This work was supported by North Carolina Biotechnology Center grant BRG-1206.

\section{Author details}

'Department of Internal Medicine, Division of Pulmonary and Critical Care Medicine, The Brody School of Medicine, East Carolina University, 3E-149 Brody Medical Sciences Building, Greenville, NC 27834, USA. ²Department of Pathology, East Carolina University, Greenville, USA. ${ }^{3}$ Department of Physiology, East Carolina University, Greenville, USA. ${ }^{4}$ Department of Microbiology and Immunology, East Carolina University, Greenville, USA

Received: 12 October 2012 Accepted: 15 January 2013 Published: 23 January 2013

\section{References}

1. Crawley T, Koponen P, Tolvas L, Marttila T: Finance and investor models in nanotechnology, Report: OECD/NNI International Symposium on Assessing the Economic Impact of Nanotechnology; Background Paper 2. 2012:1-13.

2. Lam CW, James JT, McCluskey R, Arepalli S, Hunter RL: A review of carbon nanotube toxicity and assessment of potential occupational and environmental health risks. Crit Rev Toxicol 2006, 36:189-217.

3. Hirano S: A current overview of health effect research on nanoparticles. Environ. Health Prev. Med 2009, 14:223-225.

4. Chen ES, Moller DR: Sarcoidosis-scientific progress and clinical challenges. Nat Rev Rheumatol 2011, 7:457-467.

5. Newman LS, Rose CS, Bresnitz EA, Rossman MD, Barnard J, Frederick M, Terrin ML, Weinberger SE, Moller DR, McLennan G, Hunninghake G, DePalo L, Baughman RP, lannuzzi MC, Judson MA, Knatterud GL, Thompson BW, Teirstein AS, Yeager H Jr, Johns CJ, Rabin DL, Rybicki BA, Cherniack R: A case control etiologic study of sarcoidosis: environmental and occupational risk factors. Am J Respir Crit Care Med 2004, 170:1324-1330.

6. Prezant DJ, Dhala A, Goldstein A, Janus D, Ortiz F, Aldrich TK, Kelly KJ: The incidence, prevalence, and severity of sarcoidosis in New York City firefighters. Chest 1999, 116:1183-1193.

7. Izbicki G, Chavko R, Banauch Gl, Weiden MD, Berger Kl, Aldrich TK, Hall C, Kelly KJ, Prezant DJ: World Trade Center "sarcoid-like" granulomatous pulmonary disease in New York City Fire Department Rescue Workers. Chest 2007, 131:1414-1423.

8. Wu M, Gordon RE, Herbert R, Padilla M, Moline J, Mendelson D, Litle V, Travis WD, Gil J: Case report: Lung disease in World Trade Center responders exposed to dust and smoke: carbon nanotubes found in the lungs of World Trade Center patients and dust samples. Environ Health Perspect 2010, 118:499-504.

9. Lam CW, James JT, McCluskey R, Hunter RL: Pulmonary toxicity of singlewall carbon nanotubes in mice 7 and 90 days after intratracheal instillation. Toxicol Sci 2004, 77:126-134.

10. Shvedova AA, Kisin ER, Mercer R, Murray AR, Johnson VJ, Potapovich Al, Tyurina YY, Gorelik O, Arepalli S, Schwegler-Berry D, Hubbs AF, Antonini J, Evans DE, Ku BK, Ramsey D, Maynard A, Kagan VE, Castranova V, Baron P: Unusual inflammatory and fibrogenic pulmonary responses to singlewalled carbon nanotubes in mice. Am J Physiol Lung Cell Mol Physiol 2005, 289:L698-L708.

11. Warheit DB, Laurence BR, Reed KL, Roach DH, Reynolds GA, Webb TR: Comparative pulmonary toxicity assessment of single-wall carbon nanotubes in rats. Toxicol Sci 2004, 77:117-125.

12. Huizar I, Malur A, Midgette YA, Kukoly C, Chen P, Ke PC, Podila R, Rao AM, Wingard CJ, Dobbs L, Barna BP, Kavuru MS, Thomassen MJ: Novel murine model of chronic granulomatous lung inflammation elicited by carbon nanotubes. Am J Respir Cell Mol Biol 2011, 45:858-866.

13. Kunkel SL, Lukacs NW, Strieter RM, Chensue SW: Animal models of granulomatous inflammation. Semin Respir Infect 1998, 13:221-228.

14. Straus DS, Glass CK: Anti-inflammatory actions of PPAR ligands: new insights on cellular and molecular mechanisms. Trends Immunol 2007, 28:551-558.

15. Culver DA, Barna BP, Raychaudhuri B, Bonfield TL, Abraham S, Malur A, Farver CF, Kavuru MS, Thomassen MJ: Peroxisome proliferator-activated receptor gamma activity is deficient in alveolar macrophages in pulmonary sarcoidosis. Am J Respir Cell Mol Biol 2004, 30:1-5.
16. Malur A, Mccoy AJ, Arce S, Barna BP, Kavuru MS, Malur AG, Thomassen MJ: Deletion of PPARg in alveolar macrophages is associated with a Th-1 pulmonary inflammatory response. J Immunol 2009, 182:5816-5822.

17. O'Regan AW, Hayden JM, Body S, Liaw L, Mulligan N, Goetschkes M, Berman JS: Abnormal pulmonary granuloma formation in osteopontin-deficient mice. Am J Respir Crit Care Med 2001, 164:2243-2247.

18. Maus UA, Koay MA, Delbeck T, Mack M, Ermert M, Ermert L, Blackwell TS, Christman JW, Schlondorff D, Seeger W, Lohmeyer J: Role of resident alveolar macrophages in leukocyte traffic into the alveolar air space of intact mice. Am J Physiol Lung Cell Mol Physiol 2002, 282:L1245-L1252.

19. Ashkar S, Weber GW, Panoutsakopoulou V, Sanchirico ME, Jansson M, Zawaideh S, Rittling SR, Denhardt DT, Glimcher MJ, Cantor H: Eta-1 (Osteopontin): an early component of Type-1 (cell mediated) immunity. Science 2000, 287:860-864

20. Carlson I, Tognazzi K, Manseau EJ, Dvorak HF, Brown LF: Osteopontin is strongly expressed by histiocytes in granulomas of diverse etiology. Lab Invest 1997, 77:103-108.

21. Oyama Y, Akuzawa N, Nagai R, Kurabayashi M: PPAR\{gamma\} ligand inhibits osteopontin gene expression through interference with binding of nuclear factors to A/T-Rich sequence in THP-1 cells. Circ Res 2002, 90:348-355

22. O'Regan AW, Hayden JM, Berman JS: Osteopontin augments CD3mediated interferon-gamma and CD40 ligand expression by T cells, which results in IL-12 production from peripheral blood mononuclear cells. J Leukoc Biol 2000, 68:495-502.

23. Li X, O'Regan AW, Berman JS: IFN-g induction of osteopontin expression in human monocytoid cells. J Interferon Cytokine Res 2003, 23:259-265.

24. O'Regan AW, Chupp GL, Lowry JA, Goetschkes M, Mulligan N, Berman JS: Osteopontin is associated with T cells in sacroid granulomas and has T cell adhesive and cytokin-like properties in vitro. J Immunol 1999, 162:1024-1031.

25. Devergne O, Emilie D, Peuchmaur M, Crevon MC, D'Agay MF, Galanaud P: Production of cytokines in sarcoid lymph nodes: preferential expression of interleukin-1 beta and interferon-gamma genes. Hum Pathol 1992, 23:317-323.

26. Bergeron A, Bonay M, Kambouchner M, Lecossier D, Riquet $M$, Soler $P$, Hance A, Tazi A: Cytokine patterns in tuberculous and sarcoid granulomas. J Immunol 1997, 159:3034-3043.

27. Shigehara K, Shijubo N, Ohmichi M, Takahashi R, Kon S, Okamura H, Kurimoto M, Hiraga Y, Tatsuno T, Abe S, Sato N: IL-12 and IL-18 are increased and stimulate IFN-y production in sarcoid lungs. J Immunol 2001, 166:642-649.

28. Barna BP, Culver DA, Abraham S, Malur A, Bonfield TL, John N, Farver CF, Drazba JA, Raychaudhuri B, Kavuru MS, Thomassen MJ: Depressed peroxisome proliferator-activated receptor gamma (PPARgamma) is indicative of severe pulmonary sarcoidosis: possible involvement of interferon gamma (IFN-gamma). Sarcoidosis Vasc Diffuse Lung Dis 2006, 23:93-100.

29. Car BD, Meloni F, Luisetti M, Semenzato G, Gialdroni-Grassi G, Walz A: Elevated IL- 8 and MCP-1 in the bronchoalveolar lavage fluid of patients with idiopathic pulmonary fibrosis and pulmonary sarcoidosis. Am J Respir Crit Care Med 1994, 149:655-659.

30. Iyonaga $K$, Suga M, Ichiyasu H, Yamamoto T, Hiraga Y, Ando M: Measurement of serum monocyte chemoattractant protein- 1 and its clinical application for estimating the activity of granuloma formation in sarcoidosis. Sarcoidosis Vasc Diffuse Lung Dis 1998, 15:165-172.

31. Ricote $M$, Glass CK: PPARs and molecular mechanisms of transrepression. Biochim Biophys Acta 2007, 1771:926-935.

32. Newman KL, Newman LS: Occupational causes of sarcoidosis. Curr Opin Allergy Clin Immunol 2012, 12:145-150.

doi:10.1186/1465-9921-14-7

Cite this article as: Huizar et al:: The role of PPARy in carbon nanotubeelicited granulomatous lung inflammation. Respiratory Research 2013 14:7. 